\title{
Cold-Adapted Variants of Influenza Virus A
}

\section{Comparison of the Genetic Properties of ts Mutants and Five Cold-Adapted Variants of Influenza Virus A}

\author{
S. B. SPRING ${ }^{1}$ H. F. MAASSAB, ${ }^{*, 2}$ A. P. KENDAL, $\dagger$ \\ B. R. MURPHY, AND R. M. CHANOCK
}

\begin{abstract}
Laboratory of Infectious Diseases, National Institute of Allergy and Infectious Diseases, National Institutes of Health, Bethesda, Maryland 20014; *Department of Epidemiology, School of Public Health, University of Michigan, Ann Arbor, Michigan 48104; and $\dagger$ Respiratory Virology Branch, Bureau of Laboratories, Center for Disease Control, Atlanta, Georgia 30333
\end{abstract}

Accepted November 3, 1976

\begin{abstract}
The genetic properties of seven cold-adapted variants of influenza virus A were compared with those of nine 5-fluorouracil (5-FU)-induced ts mutants. The 5-FU mutants had previously been placed into seven complementation-recombination groups; five of the seven cold-adapted variants also had the $t s$ phenotype, and all five were shown to share the group 1 lesion. Three of the cold variants also had additional ts lesions.
\end{abstract}

\section{INTRODUCTION}

Recent attempts to control influenza A virus epidemic and pandemic disease by live virus vaccination have involved the production of updated vaccine strains by transfer of gene(s) conferring attenuation from attenuated donors to the current epidemic wild-type (wt) subtype (Beare and Hall, 1971; Beare and McCahon, 1972; Fenner, 1972; Maassab et al., 1972; McCahon and Schild, 1972; Murphy et al., 1973, 1974; Beare et al., 1975). Three types of donor viruses have been suggested: (i) temperature-sensitive $(t s)$ mutants (often derived by mutagenesis) which are restricted in their ability to produce plaques at 38 or $39^{\circ}$; (ii) cold-adapted variants which can replicate equally well at 25 and $33^{\circ}$, while the wt parent can replicate only at $33^{\circ}$; and (iii) viruses attenuated by passage in eggs or tissue culture. Vaccine strains prepared by each of these methods appear to be attenuated both in man and

${ }^{1}$ Address reprint requests to Dr. Spring.

${ }^{2}$ Supported in part by the office of the U.S. Army Medical Research and Development Command, Department of the Army, under Research Contract DADA 17-73-C-3060. animals when compared with the homologous wild-type parent (Maassab, 1967, 1969, 1970; Boudreault et al., 1968; Maassab et al., 1969, 1972; Mills et al., 1969; Smorodincev, 1969; Beare et al., 1971; Beare and Hall, 1971; Mills and Chanock, 1971; Beare and McCahon, 1972; McCahon and Schild, 1972; Murphy et al., 1972, 1973, 1974, 1976; Edwards et al., 1972; Izuchi and Mizutani, 1973; Mizutani and Izuchi, 1973; Davenport et al., 1975; Beare et al., 1975; Richman et al., 1975; Spring et al., 1975b). However, ts mutants and cold variants have the potential advantage that they possess in vitro markers which are associated with attenuation. These markers can be assessed in tissue culture before the viruses are evaluated in man.

A set of nine temperature-sensitive mutants of influenza A derived by mutagenesis with 5-fluorouracil (5-FU) has recently been placed into seven complementation groups (Spring et al., 1975b) on the basis of a complementation-recombination assay carried out directly on the tissue culture monolayer. Previous studies (Maassab, 1967; Medvedeva et al., 1969; Maassab, 1969, 1970; Maassab et al., 1969) have suggested that cold-adapted variants of influ- 
enza virus are temperature sensitive in chick kidney tissue culture. We therefore sought to use the $5 \mathrm{FU}$ mutants as genetic probes to ascertain whether the two sets of viruses shared $t s$ lesions.

\section{MATERIALS AND METHODS}

\section{Viruses}

(i) ts Mutants. The production and characterization of the $t s$ mutants and $t s$ recombinants used as prototypes for each of the complementation groups have been detailed previously (Murphy et al., 1975; Richman et al., 1975; Spring et al., 1975a,b).

(ii) Cold-adapted variants. Two methods were used in the production of cold variants: (i) The A/AA/Marton/43 (H0N1), $\mathrm{A} / \mathrm{FM} / 1 / 47$ (H1N1), and A/AA/6/60 (H2N2) strains were adapted by multiple successive passages in chick kidney tissue culture at progressively lower temperatures (intervals of $3^{\circ}$ ) (Maassab, 1967). (ii) The A/AA/2/65 (H2N2), A/AA/2/67 (H2N2), A/ $\Lambda$ ichi/2/68 (H3N2), and A/AA/1/70 (H3N2) strains were cold-adapted by a second method: The parental strain was passaged three times in chick kidney tissue culture at $25^{\circ}$; plaques were then selected at $25^{\circ}$ in this same cell line (Maassab, 1970). The properties of these viruses are summarized in Table 1.

\section{Antigenic Analysis}

The subtype of the hemagglutinin antigen was determined by hemagglutination inhibition (HI) using A/AA/Marton/43 (H0N1), A/Great Lakes/389/1965 (H2N2), and $\mathrm{A} / \mathrm{HK} / \mathrm{X}-31 / 68$ (H3N2) as reference antigens. Reference antisera were produced in chickens to the $\mathrm{A} / \mathrm{AA} / \mathrm{Marton} / 43$ (H0N1), A2/Taiwan/1/64 (H2N2), and A/Aichi/2/68 (H3N2) strains.

Procedures similar to the WHO test protocol for neuraminidase specificity were employed (Aymard-Henry et al., 1973). Antiserum to the N1 antigen was prepared in chickens using the $\mathrm{H}$ equi $1 \mathrm{~N} 1$ (Bel) recombinant as antigen; antiserum to the N2 antigen was prepared using the $H$ equi $1 \mathrm{~N} 2$ (Aichi) recombinant as antigen.

\section{Growth and Assay of Infectious Virus}

Suspensions of $t s$ mutants or cold variants were prepared by allantoic inoculation of 10-day-old embryonated eggs and harvest of the allantoic fluid after $48-72 \mathrm{hr}$ of incubation at $33^{\circ}$. Embryonated eggs were obtained from either Truslow Farms (Chestertown, Maryland) or SPAFAS Inc. (Storrs, Connecticut).

Plaque assays were performed using rhesus monkey kidney (RMK) monolayers grown on plastic petri dishes. An agar overlay consisting of $0.9 \%$ agarose, medium L-15, and antibiotics was used (Mills and Chanock, 1971; Murphy et al., 1974). In studies performed at restrictive temperatures $\left(37,38\right.$, and $\left.39^{\circ}\right)$, the tissue culture plates were sealed in steel boxes which were placed in a constant-temperature circulating water bath (maximum variation, $0.05^{\circ}$ ). Tissue cultures were purchased from Flow Laboratories, Inc. (Rockville, Maryland).

Studies comparing the efficiency of plating of virus strains and isolates at 25 or $33^{\circ}$ were carried out in chick kidney (CK) cultures. The preparation of these cells from 1- to 4-day-old chicks and the assay procedure have been previously described (Maassab, 1967, 1969). The cells in such cultures are predominantly cpitheloid, but fibroblast-like cells are also in evidence.

\section{Complementation-Recombination Assay}

The technique for the detection of complementation-recombination on the assay plate has been described in detail previously (Mills and Chanock, 1971; Spring et al., 1975b) and is summarized in Results.

\section{RESULTS}

\section{Antigenic Analysis}

Evaluation by $\mathrm{HI}$ and neuraminidase inhibition (NI) indicated that each of the cold variants had the surface antigens of the wild-type parent (Table 1).

\section{Characterization of Cold-Adapted Var- iants with Respect to Efficiency of Plaque Formation (EOP)}

Replicate sets of CK monolayers were inoculated with serial dilutions of cold var- 
iants or parental wt strains and incubated for 3-5 days at 25 or $33^{\circ}$. The titer in plaque-forming units (PFU) per milliliter at each temperature was then calculated. Table 2 presents the log reduction of the titer at $25^{\circ}$ with respect to the titer at $33^{\circ}$. These data indicate that each of the cold variants produced plaques with high efficiency at $25^{\circ}$, whereas the wt parent of each variant did not induce plaques at this temperature.

Replicate sets of RMK monolayers were inoculated with serial dilutions of the cold variants or parental wt strains and incubated for 3 days at 37,38 , or $39^{\circ}$ or for 5 days at $33^{\circ}$; the titer in PFU per milliliter at each temperature was then calculated. Table 2 presents the log reduction of the

TABLE 1

ts Lesions in Cold Variants

\begin{tabular}{|c|c|c|c|c|}
\hline Cold variant & Method of derivation" & $\begin{array}{l}\text { Shared lesions } \\
\text { (complemen- } \\
\text { tation group) }\end{array}$ & $\begin{array}{l}\text { Shutoff tem- } \\
\text { perature }^{*}\end{array}$ & $\begin{array}{c}\text { Antigenic sub- } \\
\text { type }^{d}\end{array}$ \\
\hline A/AA/Marton/43-H0N1 & Stepwise & - & $>39$ & $\mathrm{H}_{4,3} \mathrm{~N}_{4,3}$ \\
\hline $\mathrm{A} / \mathrm{FM} / 1 / 47-\mathrm{H} 1 \mathrm{~N} 1$ & Stepwise & - & $>39$ & $\mathrm{H} 1_{47} \mathrm{~N} 1_{47}$ \\
\hline $\mathrm{A} / \mathrm{AA} / 6 / 60-\mathrm{H} 2 \mathrm{~N} 2$ & Stepwise & 1 & 37 & $\mathrm{H} 2_{60} \mathrm{~N} 2_{6 v}$ \\
\hline $\mathrm{A} / \mathrm{AA} / 2 / 65-\mathrm{H} 2 \mathrm{~N} 2$ & Plaque selection & 1 & 38 & $\mathrm{H} 2_{65} \mathrm{~N}_{65}$ \\
\hline $\mathrm{A} / \mathrm{AA} / 2 / 67-\mathrm{H} 2 \mathrm{~N} 2$ & Plaque selection & $1,3,5$ & 37 & $\mathrm{H} 2_{67} \mathrm{~N} 2_{67}$ \\
\hline A/Aichi/2/68-H3N2 & Plaque selection & 1,6 & 38 & $\mathrm{H} 3_{68} \mathrm{~N} 2_{68}$ \\
\hline $\mathrm{A} / \mathrm{AA} / 1 / 70-\mathrm{H} 3 \mathrm{~N} 2$ & Plaque selection & $1,3,6$ & 38 & $\mathrm{H} 3_{70} \mathrm{~N} 2_{70}$ \\
\hline
\end{tabular}

"Reviewed in Maassab, 1970; summarized in Materials and Methods.

"Determined by complementation-recombination assay on RMK monolayers using 5-FU-Hong Kong- $t s$ mutants and recombinants as prototypes.

" Taken as temperature at which there is a 100 -fold or greater loss in plaquing efficiency on RMK monolayers.

"Determination described in text.

TABLE 2

Plaquing Efficiency of Cold-Adapted Variants and Parental Strains at Permissive and Restrictive TEMPERATURES

\begin{tabular}{|c|c|c|c|c|c|}
\hline \multirow[t]{2}{*}{ Virus } & \multirow{2}{*}{$\begin{array}{l}\text { Log reduction } \\
\text { in plaque titer } \\
\text { at } 25^{\circ} \text { from ti- } \\
\text { ter observed } \\
\text { at } 33^{\circ} \text { in CK } \\
\text { tissue culture }\end{array}$} & \multicolumn{3}{|c|}{$\begin{array}{l}\text { Log reduction of plaque titer at indicated } \\
\text { restrictive temperature from titer ob- } \\
\text { served at permissive temperature }\left(33^{\circ}\right) \text { in } \\
\text { RMK tissue culture }\end{array}$} & \multirow[t]{2}{*}{$\begin{array}{l}\text { Shutoff tem- } \\
\text { perature in } \\
\text { RMK cells's } \\
\left({ }^{\circ} \mathrm{C}\right)\end{array}$} \\
\hline & & $37^{\circ}$ & $38^{\circ}$ & $39^{\circ}$ & \\
\hline \multicolumn{6}{|l|}{ Cold variants } \\
\hline A/AA/Marton/43-H0N1 & 0.2 & N.D. & N.D. & 1.0 & $>39$ \\
\hline $\mathrm{A} / \mathrm{FM} / 1 / 47-\mathrm{H} 1 \mathrm{~N} 1$ & 0.6 & N.D. & N.D. & 1.0 & $>39$ \\
\hline $\mathrm{A} / \mathrm{AA} / 6 / 60-\mathrm{H} 2 \mathrm{~N} 2$ & -0.1 & $>5.9$ & $>5.9$ & $>5.9$ & 37 \\
\hline $\mathrm{A} / \mathrm{AA} / 2 / 65-\mathrm{H} 2 \mathrm{~N} 2$ & 1.2 & 0.3 & $>4.9$ & $>4.9$ & 38 \\
\hline $\mathrm{A} / \mathrm{AA} / 2 / 67-\mathrm{H} 2 \mathrm{~N} 2$ & 0.2 & 2.8 & $>5.7$ & $>6.5$ & 37 \\
\hline A/Aichi/2/68-H3N2 & 0.2 & 1.8 & $>5.8$ & $>5.8$ & 38 \\
\hline A/AA/1/70-H3N2 & 0.5 & 1.0 & $>5.9$ & $>5.9$ & 38 \\
\hline \multicolumn{6}{|l|}{ Parental strains } \\
\hline A/AA/Marton/43-H0N1 & $>6.7$ & 0.0 & 0.0 & 0.0 & $>39$ \\
\hline $\mathrm{A} / \mathrm{FM} / 1 / 47-\mathrm{H} 1 \mathrm{~N} 1$ & $>6.9$ & N.D. & N.D. & 0.0 & $>39$ \\
\hline $\mathrm{A} / \mathrm{AA} / 6 / 60-\mathrm{H} 2 \mathrm{~N} 2$ & $>8.3$ & 0.0 & 0.0 & 0.0 & $>39$ \\
\hline $\mathrm{A} / \mathrm{AA} / 2 / 65-\mathrm{H} 2 \mathrm{~N} 2$ & $>6.8$ & N.D. & N.D. & 1.0 & $>39$ \\
\hline $\mathrm{A} / \mathrm{AA} / 2 / 67-\mathrm{H} 2 \mathrm{~N} 2$ & $>6.9$ & N.D. & N.D. & 0.0 & $>39$ \\
\hline A/Aichi/2/68-H3N2 & $>7.3$ & N.D. & N.D. & 0.0 & $>39$ \\
\hline A/AA/1/70-H3N2 & $>6.9$ & N.D. & N.D. & 0.0 & $>39$ \\
\hline
\end{tabular}

" Defined as a 100 -fold or greater reduction in plaquing efficiency on RMK monolayers.

Not done. 
titer at each of the three restrictive temperatures with respect to the titer at the permissive temperature $\left(33^{\circ}\right)$. The shutoff temperature of each mutant was arbitrarily chosen as the lowest temperature at which there was a 100 -fold or greater decrease in titer. The values shown in Table 2 represent the average log reduction of two or three tests on different lots of RMK cells. None of the parental viruses was restricted significantly in plaquing efficiency at $39^{\circ}$. Only the A/AA/2/65 strain produced fewer plaques at $39^{\circ}$, and, in this instance, the restriction was only 10 -fold. In contrast, five of the seven cold variants were temperature sensitive and sufficiently restricted in plaque formation at $39^{\circ}$ to permit genetic analysis with the prototype 5-FU ts mutants. Two of the cold variants were not sufficiently temperature sensitive to be analyzed by complementation-recombination with the prototype 5FU ts mutants.

\section{Genetic Characterization of Cold-Adapted Variants}

The five $t s$ cold-adapted variants were analyzed by the plate complementationrecombination technique to determine in which complementation group or groups they belonged. The nine 5-FU mutants previously assigned to seven complementation groups were used as prototype strains for this purpose (Spring et al., 1975b).

Pairs of mutants were mixed and incubated at $4^{\circ}$ for $18 \mathrm{hr}$. Serial dilutions of the mixtures were made and inoculated onto RMK monolayer cultures. The cultures were then incubated at $39^{\circ}$. Replicate monolayers were also inoculated with each individual mutant and incubated at $33^{\circ}$ or $39^{\circ}$. The resulting titer at $33^{\circ}$ was used to estimate the input multiplicity. Few if any plaques developed following incubation of singly infected cultures at $39^{\circ}$; in those instances in which a mutant produced a small number of plaques at $39^{\circ}$, the appropriate adjustment was made in calculating the number of plaques expected following dual infection with other mutants at restrictive temperature. In each test, one or more wild-type strains were assayed at $33^{\circ}$ and $39^{\circ}$, and the titers for each virus were always approximately equal at the two temperatures.

When dually infected cell monolayers were incubated at $39^{\circ}$, the number of plaques which developed varied from none for certain pairs of mutants to a quantity which equalled or exceeded the number expected assuming a Poisson distribution of dually infected cells and an efficiency of plaque formation by such cells of $100 \%$. Mutant pairs such as A/AA/Marton/6/60cold variant and $t s 463$ for which the ratio of observed to expected plaques was greater than 1 (Table 3 ) were assumed to possess $t s$ lesions in different cistrons of their genome. Thus, each of the viruses could supply the biochemical function which was defective in the other, resulting in complementation followed by reassortment of the viral genomes. Mutant pairs which failed to produce plaques at the restrictive temperature, e.g., $\mathrm{R} 1$ and $\mathrm{A} / \mathrm{AA} /$ Marton/6/60-cold variant, were assumed to have $t s$ lesions in the same cistron of their genome. The results summarized in Table 3 represent at least four tests for each mutant pair. The data suggested that all five $t s$ cold-adapted viruses shared the $t s$ lesion represented by complementation group 1 . In addition, the cold variants derived from the 1967, 1968, and 1970 strains appeared to possess additional lesions. The findings are summarized in Tables 1 and 3. Three pairs of viruses exhibited variable interaction (Table 3). The values presented are consistent with the results of $70 \%$ of multiple assays (10-15 assays per pair). Variability of genetic interaction between certain pairs of mutants has been observed previously in the complementation-recombination assay, and several hypotheses have been proposed to explain it (Spring et al., 1975a).

\section{DISCUSSION}

The data presented in Tables 1 and 3 suggest that the five cold variants which are temperature sensitive share the group 1 lesion. The concurrent acquisition of a $t s$ mutation during selection for cold adaptation has also been observed with mutants of poliovirus, Japanese B encephalitis vi- 
TABLE 3

Production of Plaques at Restrictive Temperature Following Dual Infection with Putative SingleLesion $t s$ Mutants and Cold Variants ${ }^{a}$

\begin{tabular}{|c|c|c|c|c|c|c|c|c|c|}
\hline \multirow{3}{*}{$\begin{array}{c}\text { Cold-adapted var- } \\
\text { iant }\end{array}$} & \multicolumn{9}{|c|}{ Complementation group and prototype 5-FU ts viruses ${ }^{b}$} \\
\hline & \multirow{2}{*}{$\begin{array}{c}1 \\
\text { R1 }\end{array}$} & \multirow{2}{*}{$\begin{array}{c}2 \\
\text { R8 }\end{array}$} & \multirow{2}{*}{$\begin{array}{c}3 \\
2 \mathrm{C}\end{array}$} & \multirow{2}{*}{$\begin{array}{c}4 \\
304\end{array}$} & \multicolumn{2}{|c|}{5} & \multicolumn{2}{|c|}{6} & \multirow{2}{*}{$\begin{array}{c}7 \\
463\end{array}$} \\
\hline & & & & & 315 & 422 & 454 & 464 & \\
\hline $\mathrm{A} / \mathrm{AA} / 6 / 60-\mathrm{H} 2 \mathrm{~N} 2$ & $<0.001$ & 50 & 5 & 250 & 2 & 6 & 20 & 20 & 100 \\
\hline $\mathrm{A} / \mathrm{AA} / 2 / 65-\mathrm{H} 2 \mathrm{~N} 2$ & $<0.001$ & 4 & 2 & 20 & 5 & 33 & 3 & 1 & 20 \\
\hline $\mathrm{A} / \mathrm{AA} / 2 / 67-\mathrm{H} 2 \mathrm{~N} 2$ & $<0.003$ & 1 & $<0.001^{\prime}$ & 6 & $<0.01$ & $<0.01$ & 1 & 1 & 20 \\
\hline A/Aichi/2/68-H3N2 & $<0.002$ & $1^{r}$ & 10 & 2 & 10 & 2 & $<0.001$ & $<0.01$ & 10 \\
\hline A/AA/1/70-H3N2 & $<0.01$ & 5 & $<0.001^{\circ}$ & 10 & 1 & 1 & $<0.01$ & $<0.002$ & 10 \\
\hline
\end{tabular}

${ }^{a}$ Values are based on Poisson distribution, assuming that it is necessary for a cell to receive 1 plaqueforming unit of each virus to produce a plaque at $39^{\circ}$. The formula $\left(1-e^{m A}\right)\left(1-e^{m B}\right)$ (number of cells) is used where $m A$ and $m B$ are the input multiplicities of the infecting viruses. Values are representative of a minimum of four tests between each pair. Each test was carried out on a separate lot of RMK cells, and calculations of input virus were based on the titer at $33^{\circ}$ of each mutant on that lot of cells.

${ }^{b}$ Spring et al. (1975b).

" Variable interaction was exhibited in these crosses. From 10 to 15 tests were carried out for these pairs, and the values presented are consistent with $70 \%$ of the tests.

rus, and measles virus (Dubes and Chapin, 1956; Dubes and Wenner, 1957; Hammon et al., 1963; Hozinski et al., 1966). Since the five cold variants of influenza were independently derived, it appears that the process of low-temperature selection may preferentially select viruses with $t s$ lesions on the complementation group 1 portion of the genome. Spontaneous or mutagen-induced mutants of influenza A (Hirst, 1973; Sugiura et al., 1972, 1975) or mutagen-induced mutants of fowl plaque virus (Markushin and Ghendon, 1973; Scholtissek and Bowles, 1975) often appear to occur preferentially in one or two complementation groups. Preliminary findings suggest that the group 1 lesion may be associated with a defect in cRNA synthesis and probably with the transcriptase complex. ${ }^{3}$ It is likely that the first obstacle to replication of a negative-strand virus would be the synthesis of cRNA which functions as mRNA and thus starts the synthesis of viral products. If the group 1 function is an enzyme, it is possible that ccrtain mutations result in altered en-

\footnotetext{
3 These data are based on complementation-recombination studies (Spring and Chanock, manuscript in preparation) between the 5-Fu Hong Kong $t s$ prototypes and the WSN $t s$ mutants which have been studied biochemically by Sugiura et al. (1975) and by Krug et al. (1975).
}

zyme conformation and, consequently, a shift in the temperature optimum such that the enzyme activity would be both cold adapted and $t s$, whereas other alterations in the amino acid sequence may induce only cold adaptation.

However, these findings do not preclude more than one cistron being involved in the cold adaptation property: (i) There are two cold variants, A/AA/Marton/43 (H0N1) and A/FM/1/47 (H1N1), which are cold-adapted and not $t s$. (ii). Additional $t s$ lesions are also present in three cold variants, A/AA/2/57 (H2N2), A/Aichi/2/68 (H3N2), and A/AA/1/70 (H3N2). It is noteworthy that the group 5 and 6 lesions in these viruses also appear to involve cRNA and vRNA, respectively. ${ }^{3}$ Studies are currently in progress to segregate by recombination the groups $1,3,5$, and 6 ts lesions occurring in multilesioned cold variants and to ascertain whether single lesion $t s$ segregants retain the cold-adaptation property.

\section{ACKNOWLEDGMENTS}

The expert technical assistance of Mrs. Helen Lester and Mr. W. Lee Cline is greatly appreciated.

\section{REFERENCES}

Aymard-Henry, M., Coleman, M. T., Dowdle, W. R., Laver, W. G., Schild, G. C., and Webster, R.

G. (1973). Influenza virus neuraminidase and 
neuraminidase-inhibition test procedures. Bull. WHO 48, 199-202.

Beare, A. S., and Hall, T. S. (1971). Recombinant influenza $A$ viruses as live vaccines for man. Lancet 2, 1271-1273.

Beare, A. S., Maassab, H. F., Tyrrell, D. A. J., Slepuskin, A. N., and Hald, 'T. S. (1971). A comparative study of attenuated influenza viruses. Bull. WHO 44, 593-598.

Beare, A. S., and McCahon, D. (1972). Virulence and infectivity of influenza $A$ viruses in relation to surface antigens. In "International Symposium on Influenza Vaccines for Men and Horses" (F. T. Perkins and R. H. Regamey, eds.), Symposium Series in Immunobiological Standards Vol. 20, pp. 144-151. S. Karger, Basel.

Beare, A. S., Schild, G. C., and Craig, J. W. (1975). Trials in man with live recombinants made from $\mathrm{A} / \mathrm{PR} / 8 / 34$ (H0N1) and wild H3N2 influenza viruses. Lancet 1, 729-732.

Boudreault, A., Lussier, G., and Pavilanis, V. (1968). Caracteres biologiques de souches du virus de l'influenza adaptees a $29^{\circ} \mathrm{C}$ et a $41^{\circ} \mathrm{C}$. Canad. $J$. Microbiol. 14, 867-874.

Davenport, F. M., Hennessy, A. V., Minuse, E., MaAssab, H. F., Anderson, G. R., Mitchei, J R., Heffelfinger, J. C., and Barret, C. D., JR. (1975). Pilot studies on mono and bivalent live attenuated influenza virus vaccines. In "Proceedings. Symposium on Live Influenza Vaccine," pp. 105-113. Yugoslavian Academy of Science and Arts, Zagreb.

Dubes, G. R., and Chapin, M. (1956). Cold adapted genetic variants of polio viruses. Science $124,586-$ 588.

Dubes, G. R., and WenNer, H. A. (1957). Virulence of polioviruses in relation to variant characteristics distinguishable on cells in vitro. Virology 4 , 275-296.

Fidwarns, E. A., Mammen, R. E., Rosenbaum, M J., Peckenpaugh, R. O., Michell, J. R., MaAsSab, H. F., Minuse, E., Hennessy, A. V., and Davenport, F. H. (1972). Live influenza vaccine studies in human volunteers. In "International Symposium on Influenza Vaccines for Men and Horses" (F. T. Perkins and R. H. Regamey, eds.), Symposium Series in Immunobiological Standards. Vol. 20, pp. 289-294. S. Karger, Basel.

Fenner, F. (1972). The possible use of temperature sensitive conditional lethal mutants for immunization in viral infections. Advan. Exp. Med. 31, 131-144.

Hammon, W. McD., Rohitayodhin, S., and Rhim, J. S. (1963). Studies on Japanese B encephalitis virus vaccines from tissue culture. IV. Preparation and characterization of pool of attenuated OCT-541 line and/or human vaccine trial. $J . I m$ munol. 91, 295-305.
Hirst, G. K. (1973). Mechanism of recombination. I. Factors influencing recombination rates between temperature sensitive mutants of strain WSN and the classification of mutants into complementation recombination groups. Virology 55, 81-93.

Hozinski, V. I., Seibel, V. B., Pantelyeva, N. S., Mazurova, S. M., and Novkova, E. A. (1966). The rct 40 and $\mathrm{T}_{50}$ markers and the characteristics of some variants of measles virus. Acta Virol. 10, 20-27.

Izuchi, T., and Mizutani, H. (1973). Studies on live influenza virus vaccine. I. Attenuated influenza A2 Hong Kong virus and its biological and immunological characteristics. Virology (Tokyo) 23, 134110.

Krug, R. M., Ueda, M., and Palese, P. (1975). Temperature sensitive mutants of influenza WSN defective in virus specific RNA synthesis. $J$. $V i$ rol. 16, 790-796.

MaAssab, H. F. (1967). Adaptation and growth characteristics of influenza virus at $25^{\circ} \mathrm{C}$. Nature (London) 213, 612-614.

MAassab, H. F. (1969). Biologic and immunologic characteristics of cold adapted influenza virus. $J$. Immunol. 102, 728-732.

MAassar, H. F. (1970). Development of variants of influenza virus. In "The Biology of Large RNA Viruses" (R. D. Barry and B. W. J. Mahy, eds.), pp. 542-566. Academic Press, New York.

MaAssab, H. F., Frances, T., JR., Davenport, F. M., Hennessey, A. V., Minuse, E., and AndersoN, G. (1969). Laboratory and clinical characteristics of attenuated strains of influenza virus. Bull. WHO 41, 589-594.

MaAssab, H. F., Kendal, A. P., and Davenport, F. M. (1972). Hybrid formation of influenza viruses at $25^{\circ}$. Proc. Soc. Exp. Biol. Med. 139, 768-773.

Markushin, S. G., and Ghendon, Yu. Z. (1973). Genetic classification and biological properties of temperature-sensitive mutants of fowl plaque virus. Acta Virol. 17, 369-376.

McCahon, D., and Schild, G. C. (1972). Segregation of antigenic and biological characteristics during influenza virus recombination. J. Gen. Virol. 15, 73-77.

Medvedeva, 'T'. E., Alexandrova, G. I., and SmoRodinsev, A. A. (1969). Differentiation of temperature sensitive variants of influenza $A 2$ viruses on the basis of plaque formation. J. Virol, 2, 456-460.

Mills, J., V., VAN KIRK, J., Hill, D. A., and CHANоск, R. H. (1969). Evaluation of influenza mutants for possible use in a live virus vaccine. Bull. WHO 41, 599-601.

Muls, .J., V., and Chanock, R. M. (1971). Temperature-sensitive mutants of influenza virus. I. Behavior in tissue culture and in experimental animals. J. Infect. Dis. 123, 145-157.

Mizutani, H., and Izuchi, T. (1973). Studies on 
live influenza vaccine. II. Evaluation of cold adapted influenza A2 Hong Kong in volunteers. Virology (Tokyo) 23, 141-147.

Murphy, B. R., Chalub, E. G., Nusinofy, S. R., and Chanock, R. M. (1972). Temperature-sensitive mutants of influenza virus. II. Attenuation of $t s$ recombinants for man. J. Infect. Dis. 126, 170-178.

Murphy, B. R., Chalhub, E. G., Nusinoff, S. P., Kasel, J., and Chanock, R. M. (1973). Temperature sensitive mutants of influenza virus. III. Further characterization of the ts-1[E] influenza $A$ recombinant (H3N2) virus in man. J. Infect. Dis. 128, 479-487.

Murphy, B. R., Hodes, D. S., Nusinoff, S. R., Spring-Stewart, S., Tierney, E. L., and ChanoCK, R. M. (1974). Temperature-sensitive mutants of influenza virus. V. Evaluation in man of an additional ts recombinant virus with a $39^{\circ} \mathrm{C}$ shutoff temperature. J. Infect. Dis. 130, 144-149.

Murphy, B. R., Spring, S. B., and Chanock, R. M. (1976). Live vaccine: production and use. In "Influenza: virus, vaccines and strategy" (Philip Selby, ed.), Proceedings of a working group on pandemic influenza, Rougemont 26-28, January, pp. 177-197. Academic Press, New York.

Richman, D. D., Murphy, B. R., Spring, S. B., Coleman, M. T., and Chanock, R. M. (1975). Temperature sensitive mutants of influenza virus. IX. Genetic and biological characterization of $t s-1[\mathrm{E}]$ lesions when transferred to a 1972 (H3N2) influenza A virus. Virology 66, 551-565.
Scholtissex, C., and Bowles, A. L. (1975). Isolation and characterization temperature-sensitive mutants of fowl plaque virus. Virology 67, 576-587.

Smorodincev, A. A. (1969). The efficacy of live influenza vaccines. Bull. WHO 41, 585-588.

SPRING, S. B., Nusinoff, S. R., Mills, J. V., Richman, D. D., Tierney, E. L., Murphy, B. R., and Chanock, R. M. (1975a). Temperature-sensitive mutants of influenza. VI. Transfer of $t s$ lesions from the Asian subtype of influenza A virus (H2N2) to the Hong Kong subtype (H3N2). Virology 66, 522-532.

Spring, S. B., Nusinoff, S. B., Tierney, E. L., Richman, D. D., Murphy, B. R., and Chanock, R. M. (1975b). Temperature-sensitive mutants of influenza. VIII. Genetic and biological characterization of $t s$ mutants of influenza virus A (H3N2) and their assignment to complementation groups. Virology 66, 542-550.

Sugiura, A., Tobita, K., and Kilbourne, E. D. (1972). Isolation and preliminary characterization of temperature sensitive mutants of influenza virus. J. Virol. 10, 639-647.

Sugiura, A., Ueda, M., Тobita, K., and Enomoto, C. (1975). Further isolation and characterization of temperature-sensitive mutants of influenza virus. Virology 65, 363-373.

VAN KIRK, J. E., Mills, J., V., and Chanock, R. M. (1971). Evaluation of low temperature grown influenza A2/Hong Kong Virus in volunteers. Proc. Soc. Exp. Biol. Med. 136, 34-41. 